\title{
$\mathbb{J}$ Muke $\mathfrak{Z}$ am $\mathfrak{J}$ ournal
}

\section{INCOME TAX ASPECTS OF TAX PLANNING FOR ESTATES}

\author{
Charles L. B. Lowndes*
}

T IS IMPORTANT to consider income tax, as well as estate and $I_{\text {gift tax, savings in setting up a tax plan for an estate. The primary }}$ purpose of tax planning is to save tax dollars. It does not matter whether these economies take the form of estate or gift or income tax dollars. Careful consideration of the income tax in planning an estate can result in substantial tax savings.

A plausible argument may be made to the effect that income tax planning for estates should extend to any method of avoiding income taxes, upon the theory that estate planning should not be confined to the disposition of estates, but should include any appropriate steps to avoid taxes that prevent the accumulation of an estate to dispose of. This discussion will, however, be limited to the income tax considerations connected with disposing of an estate. The difficulty with going beyond this is that there is no logical place to stop, short of the whole field of income tax planning.

The income tax considerations connected with the disposition of an estate may be divided into: (I) methods of minimizing the income tax of the owner of the estate; and (2) methods of controlling the income taxes of the estate and the beneficiaries of the estate. Regardless of whether or not this is a logically impeccable division, it affords a convenient sequence in which to consider the income tax aspects of estate planning.

* A.B. 1923, Georgetown University; LL.B. 1926, S.J.D. 1931, Harvard University. James B. Duke Professor of Law, Duke University. Author [with Robert Kramer], Federal Estate and Gift TAxation (1956). Contributor to legal perisdicals. 
Inter Vivos Transfers to Minimize the Income Tax of the OWNER OF AN ESTATE

The principal method of minimizing the income tax of the owner of an estate involves inter vivos transfers of income producing property. A man frequently divests himself of his property during his life to get it out of his taxable estate at his death. Inter vivos transfers of income producing property may also reduce the transferor's income tax by relieving him from the tax upon the income from the transferred property. There is no correlation between the estate tax and the income tax, however, and a transfer that reduces the transferor's estate tax will not necessarily save income taxes. Frequently the same transfer will save both estate and income taxes. In some situations, however, a transfer that is advantageous from the point of view of one tax may be disadvantageous from the point of view of the other, and the desirability of making the transfer must be determined by weighing these advantages and disadvantages against each other.

One thing that must be considered in making inter vivos transfers to avoid income taxes is the type of transfer, since there are some transfers that do not relieve the transferor from liability for the tax upon the income from the transferred property. Another significant factor is the character of the transferee. Obviously, there is no income tax advantage in transferring income unless it will be taxed to the transferee in a lower bracket than it will be to the transferor. Finally, the nature of the property that is transferred must be taken into account, because of the effect of the transfer upon the basis of the transferred property. Since the income tax effects of inter vivos transfers depend upon the type of transfer, the character of the transferee, and the nature of the transferred property, it will be convenient to consider them under these headings. In this connection, moreover, since the ultimate tax advantages of an inter vivos transfer depend upon the total impact of the estate and gift and income taxes, it will be desirable occasionally to contrast the income tax consequences of various types of inter vivos transfers with their effects under the estate and gift taxes.

\section{A. Type of Transfer}

When a person gives away property during his life in order to escape the tax upon the income from the property, he must make sure that he has divested himself of any interest in the property that might make 
the income taxable to him. People frequently try to give their property away for tax purposes, without abandoning all control over, or benefit from, the property. To prevent this, both the statute and what might be called the common law of taxation provide that such transfers shall be ignored taxwise. In this connection, it is important to keep constantly in mind the fact that there is no correlation between the income tax and the estate tax and the gift tax. A transfer that is regarded as complete for the purposes of one tax will not necessarily be treated as complete for the purposes of another. For example, a transfer that will remove the transferred property from the transferor's taxable estate under the estate tax may not relieve him from liability for the income tax upon the income from the property. Nor will a transfer that is taxable under the gift tax necessarily relieve the transferor from liability for the income tax upon the income from transferred property. The practical bearing of the lack of correlation between the income, estate, and gift taxes is that the tax consequences of every transfer must be tested independently under each tax. The dissimilarities as well as any similarities between the taxes must be kept in mind and any analogies applied with cautious suspicion.

\section{Grantor trusts}

Most inter vivos transfers that involve substantial amounts are effected by means of a trust. In making transfers in trust it is important to remember the statutory provisions that tax the income from a trust to the grantor of the trust. These are set forth in sections 67I through 677 of the 1954 Code. In this connection, section 678 , which taxes the income from a trust to one other than the grantor of the trust, upon the theory that he is the substantial owner of the trust corpus or income, should also be kept in mind.

It is scarcely feasible to go into the fine distinctions of sections $67 \mathrm{I}$ through 678 here. For the present purposes, it will suffice to point out in general terms the types of inter vivos trusts that will not reduce the grantor's income tax because the income from the trust will be taxed to him.

a. Reversionary interests. The first type of trust that the Internal Revenue Code disregards for purposes of the federal income tax is the short-term trust. Section 673 provides that the income from a trust shall be taxed to the grantor of the trust where he retains a reversionary interest that will, or that may reasonably be expected to, take effect in possession or enjoyment in ten years, commencing with the date of the 
transfer of the trust property to the trust. Thus, if $A$ transfers property to $T$ in trust for $C$ for nine years, the income from the trust will be taxed to $A$, despite the fact that it is distributed to $C$. If, moreover, $A$ transfers property to $T$ in trust to pay the income to $C$ during $T^{\text {'s }}$ life, the trust income will be taxed to $A$ if $T^{\text {'s }}$ life expectancy is less than ten years, since $A$ 's reversionary interest may reasonably be expected to take effect in possession or enjoyment within ten years from the creation of the trust. If the trust is to continue during the life of $C$, however, the income from the trust will not be taxed to $A$, since the statute expressly provides that the income from a trust that is to endure for the life of the income beneficiary shall not be taxed to the grantor, even though the income beneficiary's life expectancy is less than ten years. ${ }^{1}$ The statute also provides that the income from a trust for a charitable school, church, hospital, or certain medical research organizations shall not be taxed to the grantor of the trust if it is to be paid to such a beneficiary for a period of at least two years. ${ }^{2}$

As far as the estate tax is concerned, short-term trusts are not particularly desirable in planning the disposition of an estate, because the reversionary interest retained by the grantor must be included in his gross estate. Short-term trusts may be very useful, however, in avoiding income taxes, where the owner of property wishes to rid himself of the tax upon the income from the property without surrendering ultimate control of the property. Thus, for example, a wealthy man who is contributing to the support of a parent may achieve substantial tax savings by setting up a short-term trust for the parent for his life. In this case, he would incur a gift tax upon the discounted value of the trust term when he created the trust, because there is no correlation here between the gift tax and the income tax. In the normal case, however, the income tax savings would amply offset any gift tax liability.

According to the regulations, ${ }^{3}$ any income from a trust that is used

\footnotetext{
${ }^{I}$ INT. REV. CODE OF 1954, $\$ 673$ (c).

${ }^{2}$ INT. REv. CODE OF 1954, $\$ 673(\mathrm{~b})$. The income from the trust must be irrevocably payable to a particular designated charity for at least two years. Section ${ }_{673}$ (b) does not apply to the income of a trust that is irrevocably payable to University $A$ for one year and then to University $B$ for the next year, nor to income of a trust which may be allocated among several charities in the discretion of the trustee. However, section 673 (b) will apply to a trust where fixed shares of the income of the trust are irrevocably payable to designated charities for at least two years, like a trust under which the trustee is to pay one-half of the income to University $A$ and one-half of the income to University $B$ for at least two years. Treas. Reg. $\S 1.673(b)-1(b)(1956)$.

${ }^{3}$ Treas. Reg. $\S$ I.662(a) -4 (1956).
} 
to support a person whom the grantor is legally obligated to support will be taxed to the grantor to the extent that the income discharges the grantor's obligation of support. This problem also crops up in connection with sprinkling trusts and will be referred to again in that context. At this point, it will be enough to note that where a man sets up a short-term trust for a beneficiary whom he has a legal obligation to support, he must not only make sure that the trust will endure for the life of the income beneficiary or longer than ten years, he must also make sure that the income will be accumulated or used for some purpose other than to discharge his legal obligation of support. Even. though the income from a trust is not used to discharge the grantor's legal obligation to support the beneficiary of the trust, it may still be. taxable to the grantor, if the grantor has power to apply the trust income to discharge his obligation, unless he holds this power as trustee or co-trustee of the trust. ${ }^{4}$

b. Power to control beneficial enjoyment. Under section 674 of the I954 Code, the income from a trust is taxable to the grantor of the trust where the grantor or a nonadverse person or both have power to alter the beneficial enjoyment of the trust property. This provision is particularly important when a trust takes the form of a sprinkling trust. Since ordinarily the purpose of a sprinkling trust is to minimize the taxes of the trust and the beneficiaries of the trust, we shall consider sprinkling trusts in connection with that portion of our discussion. At this point, however, it is perhaps pertinent to observe that if the grantor of a trust retains power to sprinkle the income or corpus of a trust among the beneficiaries of the trust in.his discretion, either in his individual capacity or as a trustee or co-trustee, this will make the income from the trust taxable to him. Normally, the solution for this problem will be to appoint an independent trustee. Section 674 expressly provides that a power to sprinkle income or corpus among the beneficiaries of a trust will not make the income from the trust taxable to the grantor of the trust if the power is vested in "a trustee or trustees, none of whom is the grantor, and no more than half of whom are related or subordinate parties who are subservient to the wishes of the grantor," provided that no one has power to add new beneficiaries to the trust, except to take care of after-born and adopted children. ${ }^{5}$

c. Administrative powers. Even though the grantor of a trust or a

\footnotetext{
'INT. REv. CODE OF 1954, $\$ 677$ (b).

INT. REv. CODE OF 1954, \&674(c).
} 
non adverse person has no power to control the enjoyment of the trust, the income from the trust may still be taxed to the grantor, if certain administrative powers that are set forth in section 675 of the 1954 Code are vested in the grantor or a non adverse person or both. In this connection, it may be well to note that although it has been held that the retention of administrative powers will not make trust property taxable to the estate of the grantor of the trust under the estate tax, ${ }^{0}$ this may no longer be true if the administrative powers that are retained are so extensive that they are regarded as giving the grantor power to control the enjoyment of the trust property. ${ }^{7}$

The administrative powers whose rentention will make the income from a trust taxable to the grantor of the trust under section 675 include a power exercisable by the grantor or a non adverse party or both to puchase or otherwise deal with the trust corpus or income for less than an adequate consideration in money or money's worth. They also include power to borrow trust corpus or income without adequate interest or security, except where a trustee other than the grantor is authorized under a general lending power to make loans to any person without regard to interest or security. Even where there is such a general lending power in a trustee other than the grantor, the grantor will be taxable upon the income of the trust if he borrows from the trust, unless he repays the loan, with interest, before the beginning of the taxable year. Repayment is not required to avoid the tax, however, if the loan was made by an independent trustee for adequate security and interest.

In addition to powers to deal with the trust property for less than an adequate consideration and to borrow from the trust, administrative powers that make the income from the trust taxable to the grantor of the trust include powers that are held in a nonfiduciary capacity to vote stock or securities or to control investments in a corporation in which the holdings of the grantor and the trust are significant from the viewpoint of voting control. They also include power to reacquire the trust property by substituting other property of an equivalent value. In connection with these powers, it should be noted that the literal language of the statute does not exempt the grantor from liability for the income tax even when the power is vested in an adverse person as long as it may be exercised in a nonfiduciary capacity or without the consent of a person acting in such a capacity.

\footnotetext{
${ }^{6}$ Reinecke v. Northern Trust Co., 278 U.S. 339, 346-47 (1929).

${ }^{7}$ State Street Trust Co. v. United States, 263 F.2d 635 (1st Cir. 1959).
} 
d. Power to revoke. A power to revoke a trust that is vested in the grantor of the trust or a non adverse person or both will make the income from the trust taxable to the grantor under section 676 of the 1954 Code. In this connection, a divergence between the income and the estate tax should be noted. Power to alter the enjoyment of a trust or to revoke a trust may be vested in one other than the grantor of the trust, even a nonadverse person, without subjecting the trust property to a tax under sections 2036 or 2038 of the estate tax, since those sections are construed as precluding a tax where the grantor is excluded from participation in the exercise of the power. ${ }^{8}$ On the other hand, the factthat power to revoke or alter a trust is vested in one other than the grantor of the trust will not prevent the income from the trust from being taxed to the grantor of the trust, unless the power is vested in an adverse person or can only be exercised by the grantor with the consent of an adverse person. As far as the estate tax is concerned, however, if the grantor possesses power to alter or revoke a trust, even though this power can only be exercised in conjunction with an adverse person, the trust property will be taxable to his estate. ${ }^{9}$

e. Income for benefit of grantor. In creating an inter vivos trust to divert income from the grantor of the trust, care must be taken to make sure that the income from the trust may not be distributed to or accumulated for future distribution to the grantor of the trust in the discretion of some nonadverse person. Section 677 of the 1954 Code provides that the income from a trust that may be distributed to the grantor of the trust or accumulated for future distribution to the grantor in the discretion of the grantor of the trust or a nonadverse person or both shall be taxable to the grantor of the trust. In this connection, it is important to remember that under section 677 the income from a trust that may be used to discharge an obligation of the grantor of the trust is treated as income that may be distributed to the grantor of the trust and is taxable to the grantor. ${ }^{10}$ A slight exception to this rule is made where the obligation of the grantor is an obligation to support a dependent of the grantor. Section $677(\mathrm{~b})$ provides that the

${ }^{8}$ Commissioner v. Irving Trust Co., 147 F.2d 946 (2d Cir. 1945); Anna B. Kneeland, 34 B.T.A. 816 (1936). See Treas. Reg. $\$ \S 20.2036-1(b)(3), 20.2038-$ (a) (3) (1958).

${ }^{\circ}$ Helvering v. City Bank Farmers Trust Co., 296 U.S. 85 (1935).

${ }^{10}$ See Douglas v. Willcuts, 296 U.S. I (1935); Helvering v. Schweitzer, 296 U.S. 551 (1935); Helvering v. Blumenthal, 296 U.S. 552 (1935); Helvering v. Stuart, 317 U.S. 154 (1942). 
fact that there is a power to use income from a trust to support a person whom the grantor of the trust is legally obligated to support will not make the income from the trust taxable to the grantor if the income is not actually used for this purpose, unless the power is vested in the grantor. Even then, the income from the trust will not be taxed to the grantor of the trust if he can only exercise the power as a trustee or a co-trustee. Thus, for example, if $A$ transfers property in trust for his minor son $C$ and retains power, in a nonfiduciary capacity, to direct the trustee $T$ to accumulate the income from the trust or apply it for $C^{\prime}$ 's support, the income from the trust that is actually accumulated will be taxed to $A$. If, however, $A$ himself were the trustee of the trust and could only exercise the power to accumulate the income or apply it for C's support in his capacity as trustee, he would only be taxable upon the income actually used for $C$ 's support. ${ }^{11}$

In addition to taxing the income from a trust to the grantor of the trust where the trust income may be distribtued to or held for future distribution to the grantor of the trust, section 677 taxes the income from a funded insurance trust to the grantor of the trust where the grantor or a non adverse party or both have power to use the income from the trust to pay premiums on life insurance on the life of the grantor of the trust. In this connection, it is important to notice that section 677 only taxes the income from a funded insurance trust to the grantor of the trust when the income from the trust may be used to pay premiums on life insurance on the life of the grantor of the trust. Section 677 has no application to funded insurance trusts involving life insurance on one other than the grantor. Funded insurance trusts may be used advantageously to purchase insurance on the life of one other than the grantor of the trust. Thus, under the so-called grandfather trust, $A$ transfers property to $T$ in trust, with directions to purchase insurance on the life of $B$ and to use the income from the property to pay the premiums on the insurance. At $B$ 's death, $T$ is to collect the insurance and hold it, along with the other property in the trust, in trust for $B$ 's children. The advantage of this arrangement from a tax point of view is that the income used to buy insurance on $B$ 's life is taxed to the trustee in a much lower bracket than it would be taxed to $A$ or $B$, so that it buys more insurance. Moreover, the property transferred to the trustee

\footnotetext{
${ }^{11}$ If some nonadverse person, including the grantor as trustee, has power to use the trust income to discharge a legal obligation of the grantor, other than an obligation of support, the mere existence of the power will make the income from the trust taxable to the grantor. Treas. Reg. $\$ 1.677$ (b) -1 (d) $(1956)$.
} 
and the proceeds of the insurance purchased by the trustee pass to $B$ 's children without being taxed under the estate tax to the estates of $A$ or $B$.

\section{Anmuities}

It is difficult to avoid an income or an estate tax in connection with property that is given away if the donor retains the right to the income from the property during his life. The retention of the life estate will make the donated property taxable to the donor's estate under section 2036 of the estate tax, while the income from the property to which he is entitled will, of course, be taxed to him under the income tax. If a man purchases an annuity that carries no refund from a commercial company, the amount expended for the annuity will not be taxed to his estate at his death. He owns nothing at his death, and any transfer that he made during his life took the form of a bona fide purchase for an adequate consideration. Moreover, the annuitant will reduce his income tax to the extent that part of the annuity payments will be excluded from his gross income as a return of the capital invested in the annuity. ${ }^{12}$ From an estate planning point of view, however, the purchase of the annuity is not a particularly desirable arrangement, because the capital invested in the annuity is lost to the estate.

According to the Supreme Court, if a person, even an uninsurable person, buys an annuity along with a single premium policy of life insurance, the insurance will not be taxed to his estate if he completely divests himself of all incidents of ownership in the insurance during his life, provided, of course, that he lives more than three years after the assignment of the insurance, so that the assignment cannot be taxed as a transfer in contemplation of death. Even though the insurance company would not sell the insurance without the annuity, the Court says that they are independent contracts, and a complete inter vivos disposition of the insurance will remove it from the insured's taxable estate. $^{13}$

In view of the Supreme Court's position, it may be possible to effect some income and estate tax economies by investing an estate in an annuity and a single premium policy of life insurance, and immediately assigning the insurance to the person whom the purchaser of the contracts wishes to take his estate. The tax advantages of such an arrangement depend upon the mathematics of the particular situation. The

\footnotetext{
${ }^{19}$ INT. Rev. CODE OF 1954, $\$ 72($ b).

${ }^{13}$ Fidelity-Philadelphia Trust Co. v. Smith, 356 U.S. 274 (1958).
} 
income tax savings due to the realization of estate owner's income in the form of a partially tax-exempt annuity and the estate tax eliminated by removing the amounts expended for the annuity and the insurance from the purchaser's taxable estate must be compared with the gift tax incurred by the assignment of the insurance and any loss of capital represented by the excess of the sums invested in the annuity and the insurance contracts over the proceeds of the insurance.

In addition to the purchase of an annuity along with a single premium policy of life insurance, another arrangement that seems to offer an opportunity to avoid income and estate taxes in connection with a transfer of property under which the transferor reserves the right to the income from the property is the family annuity. Instead of making a gift of property to the person to whom the owner of the property wishes to give the property at his death and reserving the income from the property during his life, the owner of the property may transfer the property in consideration of the transferee's promise to pay him an annuity. If this transaction is viewed, as it usually is where the transferor retains no interest in the transferred property, as the purchase of an annuity rather than a transfer with a reservation of a life estate, the transfer will escape the gift tax and the transferred property will be eliminated from the transferor's gross estate under the estate tax. Moreover, the annuity paid to the transferor will be only partially taxable under the income tax.

The family annuity looks like the ideal method of giving away property while retaining a life interest in the property, without encountering the estate or gift taxes and treating only part of the income from the property as taxable under the income tax. There are, however, some serious income tax disadvantages, as well as some other drawbacks, connected with the family annuity that should be considered carefully before any such arrangement is entered into.

Apart from tax considerations, the family annuity may be an exceedingly hazardous arrangement because the annuitant may lose the property that he gave for the annuity and never receive the annuity. A family annuity possesses none of the security of an annuity purchased from an insurance company. It is no better than the promise of the member of the family who undertakes to pay it. The annuitant does not dare to retain any interest in the property exchanged for the annuity, because if he does, the purchase of the annuity may be treated as a transfer with a reservation of a life estate. 
As far as the income tax advantages of a family annuity are concerned, they are largely illusory. It is true that only part of the annuity payments will be taxed as income to the annuitant. The income from the property transferred to the person who undertakes to pay the annuity will, however, be fully taxed to him, while it is extremely unlikely that he will get any offsetting deductions for the annuity payments. The family income will be further increased if appreciated property was given in exchange for the annuity. Although the appreciation in the property during the time it was in the hands of the transferor will not be taxed at the time of the transfer, it will be taxed after the annuitant has excluded from his gross income part of the annuity payments equals to the basis of the property. From that point on, the part of the annuity payments that would ordinarily be excluded as gross income will be taxed as capital gain realized from the exchange of the appreciated property for the annuity until the total of these amounts equal the total gain. This means, of course, that a number of the annuity payments will be fully taxable to the annuitant partly as ordinary income and partly as capital gain. ${ }^{14}$

Another income tax drawback connected with the family annuity is the adverse basis that the person who undertakes to pay the annuity may get for the property transferred to him if the annuitant dies prematurely. The property will take as its basis the amount of the annuity payments made before the annuitant's death rather than its fair market

"t $\mathrm{A}$ simple illustration of how a family annuity works is this: When $F$ had a life expectancy of 25 years, he transferred stock that cost him $\$ 9,600$ and was worth $\$ 40,000$ to $S$ in return for an annuity of $\$ 2,000$ a year. The stock will not he taxed to $F$ 's estate under the estate tax. As far as the income tax is concerned, F's iuvestment in the contract is $\$ 40,000$ and the expected return under the contract is $\$ 50,000$ ( $\$ 2,000$ $x 2_{5}$ ). Therefore, the exclusion ratio is $\$ 40,000 / \$ 50,000$, so that 45 of the annual $\$ 2,000$ payment, or $\$ 1,600$, is excluded from gross income, and $1 \%$, or $\$ 400$, is taxed as ordinary income. After $\$ 9,600$ has been excluded from gross income, which will be at the end of 6 years, $F$ will have recovered the cost of the stock transferred for the annuity. In the succeeding years, he will, therefore, include the $\$ 1,600$ excluded from ordinary income as capital gain, until he has returned $\$ 30,400(\$ 40,000-\$ 9,600)$, the capital gain realized upon the exchange of the stock for the annuity. After that, which will be 19 years from the time when he recovered the basis of his stock, or 25 years from the purchase of the annuity, the annuitant will return \$40o out of each $\$ 2,000$ annuity payment as ordinary income and exclude $\$ 1,600$ entirely from gross income.

The computation of the basis of the stock in the hands of the transferee, $S$, is somewhat complicated. If, however, $F$ dies before $S$ disposes of the stock, $S$ 's basis for the stock will be the total amount he paid out under the annuity. If, therefore, $F$ died after $S$ had made two annuity payments, $S$ 's basis for the stock would be $\$ 4,000$, as contrasted with $\$ 40,000$ if $F$ had left the stock to him by will. 
value at the annuitant's death or the alternate valuation date, which would have been the basis of the property if it had been transmitted by death.

\section{Inter vivos gifts to charity}

If a man plans to leave property to charity, he should consider the income tax advantages of making an inter vivos gift of the property, while retaining the right to the income from the property during his life. The only advantage, from a tax point of view, of leaving property to charity by will is that the property will not be taxed to the decedent's estate under the estate tax. An inter vivos transfer of the property with a reservation of a life interest will eliminate the property from the transferor's taxable estate under the estate tax, while permitting him to enjoy the property during his life and take a deduction for the present gift of the remainder to charity from his income tax..$^{15}$

In making inter vivos gifts to charity, it is important to keep the amount of the gift within the mathematical limitations upon the deduction for contributions to charity under the income tax to avoid wasting a deduction. This may be achieved by making gifts of fractional interests in the property in order to spread the gift of the property over several taxable periods and stay within the limits of the permissible deduction.

It is also important in making inter vivos gifts to charity to remember that the deduction under the income tax is based on the fair market value of the property given to charity at the time of the gift, rather than its cost or other basis to the donor. This means, of course, that appreciated property should be donated in kind to charity in order to give the donor the advantage of deducting the appreciation in the property as a charitable contribution, without the detriment of realizing the appreciation as taxable income. By the same token, a donor should sell depreciated property and donate the proceeds to charity in order to take advantage of a tax loss, which in no way diminishes his deduction for a charitable contribution. ${ }^{16}$

\section{B. The Transferee}

Income tax savings may be achieved by inter vivos gifts of income producing property where this results in diverting income taxable to (1960).

${ }^{16}$ See Lowndes, Tax Advantages of Charitable Gifts, 46 VA. L. REV. 394, 416-20

${ }^{18} I d$. at $409-13$. 
the donor in a high bracket to a donee who is taxable in a lower bracket. There is, of course, no advantage in making gifts between spouses, as far as the income tax is concerned, since they may split their income on a joint return, and inter vivos gifts to equalize their incomes would, therefore, simply incur a gift tax without improving their income tax position. It is also obvious that income tax economies will only be affected where income is transferred to a transferee to whom it will be taxed in a lower bracket than that in which it was taxed to the transferor. Even in this case, there may be no income tax advantage in giving away income producing property if the income that is lost because of the capital that has to be used to pay the gift tax equals or exceeds the income tax saving. In this connection, it is important to remember that income tax savings in connection with inter vivos transfers can be expressed accurately only in terms of income available before and after the transfer, rather than the income taxes payable before and after the transfer. ${ }^{17}$

\section{The Transferred Property}

In making inter vivos transfers to reduce taxes, discrimination should be exercised in the selection of the property to be given away. As far as the estate tax is concerned, it is advantageous to give away property that is apt to appreciate in value, since by incurring a gift tax on the present value of the property, the donor will escape an estate tax upon its potential future value. From an income tax point of view, however, property that has increased in value, or is apt to do so in the future, should not be given away inter vivos, because the donee will take the substituted basis of the donor instead of the stepped-up basis that he would get if the donor held the property until his death. For example, if $A$ bought a share of stock for $\$ 100$ and gave it to $B$ when it was worth $\$ 200$ and $B$ sold it for that figure, $B$ would have a taxable gain of $\$$ Ioo. If, however, $A$ bequeathed the stock to $B$ and it was worth $\$ 200$ at $A$ 's

\footnotetext{
${ }^{12}$ Suppose, for example, that $A$, a single man who is not the head of a household and who has a taxable income of $\$ 20,000$ a year gives $\$ 100,000$ worth of 5 per cent bonds to his brother $B$, who is also single and is not the head of a household and who has a taxable income of $\$ 2,000$ a year, and that $A$ incurs a gift tax of $\$ 20,000$ in connection with this gift. $A$ 's income tax before the transfer ainounted to $\$ 7,260$, and $B$ 's to $\$ 400$. After the transfer, assuming that the $\$ 20,000$ that $A$ used to pay the gift tax yielded 5 per cent income, $A$ 's income will be reduced from $\$ 20,000$ to $\$ 14,000$, and his tax will be $\$ 4,260$. $B^{\prime}$ 's tax upon an income of $\$ 7,000$ will be $\$ 1,660$. Consequently, the incoine taxes paid by $A$ and $B$ will be $\$ 1,740$ less after the transfer than they were before the transfer. Since, however, they have lost the income from the money used to pay the gift tax, $\$ 1,000$, the actual savings due to the transfer only amount to $\$ 740$.
} 
death, $B$ 's basis for the stock would be $\$ 200$, and he could sell it for that figure without realizing any gain. Where there are tax advantages and disadvantages connected with a transfer, the desirability of making the transfer must be determined by weighing these conflicting considerations in the light of the particular facts of the specific situation. Thus, for example, if the donee intended to retain the stock given to him in the hypothetical situation instead of selling it, and there was a possibility that the stock would appreciate still further in value before $A$ 's death, the critical consideration would be the estate tax rather than the income tax, and it might be wise to make an inter vivos gift of the stock.

An interesting problem in tax planning may arise where a man is about to make a gift of property that has appreciated in value and that will be immediately sold. If the donee is in a lower bracket than the donor, it may be advantageous to give the property to him and let him make the sale, so that the gain will be taxed at a lower rate. In this case, however, the gift tax will attach to the full value of the property given away, while if the donor had sold the property and paid the income taxes on the gain from the proceeds and given the remaining proceeds to the donee, only the net proceeds after subtracting the income tax would have been subject to the gift tax. However, the decrease in the gift tax does not represent a pure saving, since any additional gift tax paid by the donor is added to the basis of the donated property in the donee's hands and decreases the taxable gain from the sale of the property. ${ }^{18}$

In making gifts of property to reduce income taxes, care must be taken to make sure that the property that is given away is the kind of property that will shift liability for the income tax to the donee. If, for example, a man assigns compensation for personal services, the compensation remains taxable to the assignor as far as the income tax is

\footnotetext{
${ }^{28}$ If the donor and the donee are in the same income tax brackets, the advantage seems to lie with giving the property away and letting the donee sell it, due to the fact that the additional gift tax paid by the donor will be added to the donee's income tax basis. Suppose, for example, that $A$ purchased Blackacre for $\$ 5,000$ and is about to sell it for $\$ 10,000$, its current value. He wishes to give the property or its proceeds to $B$. Assume further that any gain from the sale of the property will be taxed as a long-term capital gain at $25 \%$ to either $A$ or $B$, and that any gift that $A$ makes will incur a gift tax of 10\%. If $A$ sells the property and gives the procecds to $B$, he will incur an income tax of $\$ 1,250$ on a long-term capital gain of $\$ 5,000$ and a gift tax of $\$ 875$ on a gift of $\$ 8,750$, or a total tax of $\$ 2,125$. If $A$ gives the property to $B$ and $B$ sells the property, $A$ will incur a gift $\operatorname{tax}$ of $\$ 1,000$ and $B$ will incur an income tax of $\$ \mathrm{r}, 000$ on a capital gain of $\$ 4,000$, since $B$ 's basis for the property will include the gift tax paid by $A$, so that the total taxes will be only $\$ 2,000$.
} 
concerned. ${ }^{19}$ In the same way, if the owner of bonds cuts off unmatured coupons from the bonds and gives them away, the interest represented by the coupons will be taxable to the donor rather than the donee. ${ }^{20}$ In this connection, it should be noted that the fact that a right to income that cannot be transferred for tax purposes is assigned to a trust will not shift liability for the income tax on the income to the trust. Although section $67 \mathrm{I}$ of the 1954 Code specifies that the income from a trust shall not be taxed to the grantor of the trust or some other substantial owner of the trust, because of his "dominion and control" over the trust property, apart from some statutory provision authorizing the tax, this does not mean quite what it seems to say on the surface. As the Regulations point out, section 67 I does not prevent taxing income assigned to a trust to the assignor who created the trust upon some theory other than his "dominion and control" over the trust property. Thus, if a man assigns compensation for personal services or gives bond coupons from his bonds to a trust, the income realized from the services or bond coupons remains taxable to the assignor, just as it would if the assignment has been made without the intervention of a trust. ${ }^{21}$

\section{II}

\section{Income Taxes of the Estate and Its Beneficiaries}

There are a number of things which may be done to control the income taxes of an estate and the beneficiaries of an estate. Since some of these things involve tax-saving provisions in wills and trusts, while others consist of steps taken in the administration of an estate, it will be convenient to consider them under those headings.

\section{A. Income Tax Provisions of Wills and Trusts \\ I. Sprunkiting trusts}

One of the most popular devices for minimizing income taxes is the so-called sprinkling trust, which was referred to earlier in connection with trusts where there was a power to control beneficial enjoyment of the trust property. A sprinkling trust, as the name implies, is a trust under which someone, ordinarily the trustee, is authorized to distribute, or "sptinte", the income, and frequently the corpus, of the trust among the beneficiaries of the trust as he sees fit. The advantage of the

${ }^{10}$ Helvering v. Eubank, 3 I I U.S. 122 (1940); Lucas v. Earl, 28 I U.S. I I I (1930).

${ }^{20}$ Helvering v. Horst, $3 x_{1}$ U.S. 112 (x940). See Harrison v. Schaffner, 312 U.S. 579 (194I).

${ }_{21}$ Treas. Reg. $\S 1.67 x-1$ (c) (1956). 
sprinkling trust is that the income from the trust can be distributed to a beneficiary who needs it most and to a beneficiary to whom it will be taxed in a low bracket. For example, suppose that $H$ has a wife $W$, who has a substantial independent income, and three children. He wishes to leave his estate in trust for his wife and children. If he leaves his estate in trust for his wife for life, with a remainder to the children, the income from the estate will be taxed to the widow on top of her other income at a very high rate, even though she actually gives it to the children. If $H$ creates a sprinkling trust, the trustee can distribute the income from the trust, which $W$ does not want, to the children or accumulate it, so that it will be taxed to the children or to the trustee, all in a much lower bracket.

One of the recognized methods of reducing income taxes is to divide a large income, taxable in a high bracket, into smaller incomes, taxable in lower brackets. This may be done in connection with a sprinkling trust by creating multiple trusts. Of course, any income which is distributed to a beneficiary of a trust is taxed to the beneficiary. If, therefore, all of the income from a sprinkling trust is distributed, it will not matter whether there is one trust or several trusts. If, however, the trustee is authorized to accumulate income, any income that is accumulated will be taxed to the trustee. If there is only one trust, the accumulated income will be taxed to the trustee as one income. If there are several trusts, the income accumulated in each trust will be taxed to the trustee as a separate income. Thus, for example, in the hypothetical situation in the preceding paragraph, $H$ might provide in his will that at his death, his estate should be divided into as many equal shares as he should leave surviving children and deceased children with surviving descendants, and that each share should be held in a separate trust for the primary benefit of the child, or the descendants of a deceased child, for whom the trust was created. The trustee would be empowered in his discretion to distribute the income from each of the trusts to the child for whom the trust was created and his family, or to the descendants of a deceased child for whom the trust was created and their families, or to the widow, or to the beneficiaries of any of the other trusts, or to accumulate the income. In this way, by distributing and accumulating income, the trustee could comminute the income of the estate for tax purposes.

In addition to authorizing the trustee of the sprinkling trusts to distribute or accumulate trust income, it is frequently desirable to em- 
power him to invest trust income in life insurance on the lives of the beneficiaries. In this way, the income that is used to purchase life insurance for a beneficiary will be taxed to the trustee in a lower bracket than it would be taxed if it were distributed to the beneficiary and taxed to the beneficiary.

In creating a sprinkling trust, care must be taken in the selection of the trustee. In the case of a testamentary trust, if a beneficiary of the trust is made sole trustee, this will make the income from the trust taxable to him, regardless of whether he actually distributes the income to himself or not. ${ }^{22}$ Moreover, if his power to distribute the trust property extends to corpus, this will make the trust property taxable to his estate under section 204I of the estate tax.

Apparently, if the trustee-beneficiary can only exercise his power to sprinkle trust income with the consent of some other person, this will prevent the income that is not actually distributed to him from being taxed to him under section 678 of the code. ${ }^{23}$ If, however, his power to sprinkle extends to corpus, as well as income, the fact that the power can only be exercised in conjunction with another person, as long as he is not an adverse person, will not preclude taxing the trust property to the trustee-beneficiary's estate under section 204I of the estate tax.

A sprinkling trust may, as we have seen, be created inter vivos as well as by will. Care must be taken in the selection of the trustee of an inter vivos trust to make sure not only that the trust income will not be taxed to a beneficiary of the trust to whom it is not distributed, but that it will not be taxed to the grantor. If the grantor of the trust is made the trustee or a cotrustee of the trust, the power to sprinkle income vested in the trustees of the trust will make the trust income taxable to the grantor. The same thing is true where any nonadverse persons are made trustees and given power to sprinkle the trust income, unless at least half of the trustees are persons who are not related or subordinate to the grantor and no one is empowered to add new beneficiaries to the trust, except to take care of after-born or adopted children. ${ }^{24}$ Thus, the grantor could appoint his wife and a trust company as cotrustees of a trust for the benefit of his wife and children and the trust income would not be taxable to him, because of the sprinkling power lodged in the

\footnotetext{
${ }^{29}$ INT. REV. CODE OF 1954, \& 678 (a) (I).

${ }^{23}$ Section $678(a)(1)$ provides that the income from a trust will be taxable to a person who "has a power exercisable solely by himself to vest the corpus or the income therefrom in himself."

${ }^{24}$ INT. REV. CODE OF I $954, \S 674$ (c).
} 
trustees. Nor would the trust income be taxed to the grantor's wife as long as it was not distributed to her. Since the power to alter the enjoyment of the trust property would be vested in one other than the grantor, it would not be taxable to his estate under the estate tax. ${ }^{2 \pi}$ If, however, the sprinkling power extended to corpus as well as income, the trust property would be taxable to the wife's estate under the estate tax if she could exercise this power in favor of herself, her estate, her creditors, or the creditors of her estate. ${ }^{26}$ As a general rule, as far as tax considerations are concerned, the safest trustee for a sprinkling trust is a trust company or an independent trustee who has no beneficial interest in the trust property.

According to the Regulations, the income from a trust that is used to support a beneficiary of the trust is taxable to the person who has a duty to support the beneficiary, to the extent that it discharges his obligation of support. ${ }^{27}$ Thus, for example, if $H$ died and left his estate to a trust company in trust to distribute the income among $H$ 's widow and children, as the trustee saw fit, any income that the trustee used to support a minor child would be taxable to the widow to the extent that it discharged her duty to support the child. Even if the income were accumulated and were not used to support the child, if the widow could direct the trustee to use the income to discharge her obligation to support the child, it would apparently be taxable to her if she held the power in a non-fiduciary capacity. ${ }^{28}$ The statute expressly provides, however, that the mere existence of a power to use income from a trust to support a person whom the person holding the power is legally obligated to support does not make the income from the person taxable to the power holder if he can only exercise the power as a trustee or cotrustee. ${ }^{29}$ Therefore, in the hypothetical case, if the widow and the trust company were cotrustees, the fact that she had power to use the trust income to support the children whom she was legally obligated to support would not make the income taxable to her if it were not actually used for this purpose. All of this means, from a practical point of view, that where the beneficiaries of a trust include persons whom the grantor or some other person is legally obligated to support, it may be desirable to accumulate the income of the trust instead of distributing

\footnotetext{
${ }^{25}$ Supra note 8.

${ }^{20}$ INT. REV. CODE OF 1954, § $20 .+1$.

${ }^{27}$ Treas. Reg. $\& 1.662(a)-4$ (1956).

${ }^{28}$ Treas. Reg. $\$ 1.678(c)-1(c)(1956)$.

${ }^{20}$ INT. REV. CODE OF 1954, $§ 678(\mathrm{c})$; Treas. Reg. $\$ 1.678(\mathrm{c})-\mathrm{I}(\mathrm{a})(1956)$.
} 
it for the beneficiary's support in order to avoid having it taxed to the grantor or the person obligated to support the beneficiary. Moreover, a power to use income for the support of a beneficiary whom the grantor or some other person is obligated to support should not be given to the grantor or this other person, except in a fiduciary capacity.

\section{Fractional shares}

There are other provisions that may be inserted in wills and trusts to minimize income taxes that are less spectacular than sprinkling trusts. For example, it may be wise to provide for distribution of an estate or trust in fractional shares instead of absolute amounts to keep from realizing taxable income.

Thus, suppose that $A$ creates a trust under which the trustee is to distribute $\$ 100,000$ to $C$ when $C$ reaches twenty-five years of age, $\$ 100,000$ when he reaches thirty, and the balance of the trust property when he reaches thirty-five. If the trustee uses property having a basis of $\$ 50,000$ and a fair market value of $\$ 100,000$ to discharge one of the $\$ 100,000$ payments, the trust will realize taxable income of $\$ 50,000 .^{30}$ If, however, the trust had directed the trustee to distribute one-third of the trust fund to $C$ at age twenty-five, one-half of the remaining balance at age thirty, and the remainder at age thirty-five, the trust would not have realized any income from these distributions. In this connection, it should be noted, however, that gain realized by a trust or estate in connection with a distribution to a beneficiary is not completely disadvantageous, since the gain taxed to the trust or estate is added to the distributee's basis for the distributed property. Thus, in the hypothetical case, where the trustee distributes property worth $\$ 100,000$ that had a basis of $\$ 50,000$ to discharge the trust's obligation to pay the beneficiary $\$ 100,000$, the trust will realize income of $\$ 50,000$, but the beneficiary's basis for the property distributed to him will be $\$ 100,000{ }^{31}$ If, on the other hand, the property had been distributed to the beneficiary to satisfy his claim for one-third of the trust property, the trust would have realized no income, but the beneficiary's basis for the property distributed to him would have been only $\$ 50,000$.

\section{Basis provisions}

The way in which a gift is worded in a will or trust may affect the basis of the property in the donee's hands. For example, suppose that

\footnotetext{
${ }^{30}$ Kenan v. Commissioner, 11+ F.2d 217 (2d Cir. 19+0).

${ }^{32}$ Ibid.
} 
a father has a plant that he wishes to leave to a corporation owned by his sons. If he leaves the plant to the corporation directly, the property in the hands of the corporation will probably be treated as property acquired from a decedent and its basis will be the fair market value of the property at the date of the decedent's death or alternate valuation date. It is barely possible, if the father owned no stock in the corporation, that the transfer of the plant to the corporation might be viewed as a contribution to the capital of the corporation by one who was not a shareholder, with the result that the corporation might take a zero basis for the property. ${ }^{32}$ In any event, it is clear that the gift of the property directly to the corporation would not increase the sons' bases for their stock in the corporation. What the father should do in this situation is to leave the plant to his sons and let them contribute it to the corporation. This will increase the sons' bases for their stock in the corporation; and since the plant will be transferred to the corporation by the stockholders, there will be no question but that its basis in the hands of the corporation will be the fair market value of the plant at the date of the father's death or the alternate valuation date, if that date was used in valuing his estate. ${ }^{33}$

Suppose that a man has 1,000 shares of $X Y Z$ corporation stock that he wishes to leave to his son and that he also wishes his son to contribute $\$ 10,000$ to his estate to satisfy a bequest of that amount. A natural way to handle this situation is to provide in the father's will that the son shall have an option to buy the stock for $\$ 10,000$. In this case, however, the son's basis for the stock will be $\$ 10,000 .^{34}$ If the father leaves $\$ 90,000$ worth of stock to the son outright and gives him the privilege of buying the remaining stock for $\$ 10,000$, the son's basis for the stock will be $\$ 100,000$. It seems obvious that, from a tax point of view, this is the better way to handle the transaction, unless, of course, the option to buy all of the stock for $\$ 10,000$ is part of a buy-sell agreement under which the value of the stock will be conclusively fixed at the option price of $\$ 10,000$ for estate tax purposes.

\section{Detrimental provisions}

There are some provisions that should not be inserted in a will or trust because of their potentially harmful income tax consequences.

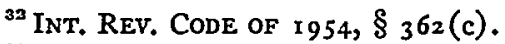

${ }^{33}$ INT. REv. CoDE OF r $954, \S 362(a)(2)$. The corporation will take the same basis for the plant as it had in the hands of the sons as inherited property.

${ }^{34}$ Mack v. Commissioner, 148 F.2d 62 (3d Cir.), cert. denied, 326 U.S. 7rg (1945).
} 
One of these is a precatory provision. For example, suppose that a man wants to leave property to his son, but since he is doubtful about the son's financial ability, he leaves the property to his brother, the son's uncle, a successful business man, and expresses the "hope" that the uncle will use the property to support his nephew and his nephew's family. From a legal point of view, this does not create a trust, but constitutes an absolute gift of the decedent's estate to the uncle. The income from the estate will, of course, be taxed to the uncle on top of his income, even though he distributes it to his nephew. Moreover, upon the uncle's death, property that he holds for his nephew and that presumably he will leave to the nephew will be taxed to the uncle's estate under the estate tax. Of course, the sound procedure in this situation would have been to leave the father's estate in trust for the son and his family, avoiding precatory expressions. This would have prevented the income from the estate from being taxed to the uncle and the property in the estate from being taxed as part of the uncle's estate at his death.

Frequently, when a person leaves money or property by will to a faithful retainer or trusted employee, the bequest is coupled with a recital that it is in recognition of or in consideration for the legatee's valuable services. It is wiser to leave out any reference to services because of the danger, albeit remote, that the bequest may be construed as taxable compensation for services, rather than a tax-free gift.

Incidentally, in connection with tax-free bequests, it may be worth noting that if a testator wishes to do something generous for his executor, he may leave him a bequest in lieu of commissions and provide that the bequest shall not be contingent upon the executor serving in that capacity. The bequest, unlike commissions, will not be taxable as income to the executor. ${ }^{35}$ Of course, the estate will lose any deduction for commissions in this case. It will frequently be possible, however, by the application of a little arithmetic, to give an executor more in the form of a tax-free bequest than he would get after income tax in commissions, without any additional cost to the estate. For example, suppose that commissions will amount to $\$ 10,000$ and the executor is in the fifty per cent bracket under the income tax, while the estate is in the thirty per cent bracket under the estate tax. If, instead of giving the executor commissions, he is given a tax-free bequest of $\$ 7,000$, he will get

\footnotetext{
${ }^{35}$ United States v. Merriam, 263 U.S. 179 (1923); Bank of New York v. Helvering, 132 F.2d 773 (2d Cir. 1943).
} 
$\$ 2,000$ more than he would have received if he had gotten commissions. The estate will not lose, because although it forfeits a deduction for commissions worth $\$ 3,000$ (thirty per cent of $\$ 10,000$ ), it will pay out $\$ 3,000$ less than it would have paid out if it had been required to pay commissions.

\section{B. Income Tax Considerations in the Administration of Estates}

There are a number of income tax problems connected with the administration of an estate whose correct solutions are important in controlling the income taxes of the estate and the beneficiaries of the estate.

\section{r. Disclaimers}

Perhaps the first thing that the executor and the beneficiaries of the estate should consider as far as taxes are concerned is whether it is desirable for a beneficiary of the estate to disclaim or renounce some interest in the estate. For example, section 678 taxes the income from a trust to a person who has power to call for the income or corpus of the trust. But section 678(d) expressly provides that the holder of the power can avoid the income tax by renouncing the power within a reasonable time after he first becomes aware of its existence. A person seeking to avoid an income tax by renouncing his power must remember, however, that the renunciation must be a complete renunciation. Section 678(a) provides that if the holder of the power releases or modifies the power in such a way that he retains an interest in the trust that would make the income of the trust taxable to a grantor who retained a similar interest, the income from the trust will still be taxable to the power holder. ${ }^{36}$

A person may disclaim an interest in an estate in order to pass the interest along to some other person without making a taxable transfer under the gift or estate taxes as long as the disclaimer takes the form of a refusal to accept an interest in the estate, as distinguished from the

\footnotetext{
${ }^{36}$ E.g., suppose that $A$ bequeaths property to $B$ in trust for $C$, but provides that $X$ may call for any income from the trust which he desires. If $X$ renounces the power completely, this will relieve him from liability for the income tax upon the income of the trust. If, however, $X$ modifies his power to call for income so that he can only exercise it with the consent of $T$, the income from the trust will still be taxablc to $X$. Although the income from the trust would not have been taxable to $X$ if the power had taken this form initially, the modification of the power does not relieve $X$ from liability for the tax upon the income from the trust, because if $X$ had created the trust and retained a power in the form of the modified power, the income from the trust would have been taxable to him as grantor of the trust.
} 
conveyance of an interest in the estate that vested involuntarily in the disclaimant. $^{37}$ In this case, of course, he will also escape an income tax, if the interest that he renounces produces income. For example, if $A$ died and left $\$ 100,000$ to $B$ and the residue of his estate to $C$, $B$ 's son, $B$ could renounce his legacy if he were independently wealthy and wished his son to take the property and escape a gift tax on the transfer of the property to his son as well as any income tax upon the future income from the property.

According to section 2055(a) of the estate tax, any bequest that passes to charity because of an irrevocable disclaimer before the due date for the estate tax return will qualify as a transfer to charity by the decedent, which is deductible by his estate. Before making any such disclaimer, however, a legatee who wishes the charity to get his interest should consider the income tax advantages of accepting the legacy and donating it to charity, since in this case, the legatee's deduction for a charitable contribution under the income tax may exceed the estate tax benefit from the disclaimer. For example, suppose that $A$ died and left $\$ 100,000$ to $B$ and the residue of his estate to $X$ charity. Suppose further that if $B$ does not renounce his legacy, the tax on $A$ 's estate will amount to $\$ 4,800$ and that $B$ is in the fifty per cent income tax bracket. Presumably, if $B$ renounces the legacy, since this is not regarded as a transfer by $B_{3}^{38} B$ will not be entitled to any deduction under the income tax, and the only tax advantage gained by the renunciation will be avoidance of the estate tax of $\$ 4,800$. By accepting the legacy and later donating it to $X$ charity, however, $B$ might save as much as $\$ 50,000$ in income taxes.

Where an executor is the principal beneficiary of an estate, he may find it advantageous to waive his commissions in order to realize the commissions in the form of an addition to the estate distributed to him, which is not subject to the income tax. In this case, the estate loses any deduction for commissions under the estate tax, so the income tax benefit must be weighed against the estate tax loss. In order to make sure that no income will be realized when the executor waives his commissions; he should waive the commissions before he starts to serve as executor. ${ }^{39}$

\footnotetext{
${ }^{37}$ See Lowndes \& Kramer, Federal Estate and Gift Taxes 682 (1956).

${ }^{38}$ Ibid.

${ }^{30}$ In Rev. Rul. 56-472, 1956-2 CUM. BuLL. 21 , the Service ruled that an executor who waived his commissions was not taxable upon the commissions as income and did not make a taxable gift of the commissions to the beneficiaries of the estate. In the factual situation ruled upon, the executor waived the commissions before his
} 


\section{Joint returns}

In addition to filing income tax returns for the estate, the executor must file a return for the decedent for the part of the taxable year when he was alive and, in some cases, for earlier years. ${ }^{40}$ If the decedent was married at the time of his death, the executor and the surviving spouse can file a joint return for the decedent and the surviving spouse. ${ }^{41}$

Although the executor may wish to file a joint return where this shows a lower tax than separate returns, this may not be permissible under the local law, because the joint return subjects the estate to liability for the income tax upon the surviving spouse's income. ${ }^{42}$ In at least three states, there are statutes that forbid an executor to file a joint return, unless he is expressly authorized to do so by the will or a court order. ${ }^{43}$ To eliminate uncertainty upon this point, the will should contain explicit authorization to the executor to join in a joint return. It may also be desirable to empower the executor to pay any part of the joint tax that he sees fit from the estate. ${ }^{44}$

\section{The estate's taxable year and method of accounting}

In addition to filing income tax returns for the decedent, the executor is required to file income tax returns for the estate. A number of questions arise in connection with the estate's income tax. Perhaps the first problem which the executor encounters is what taxable year and what system of accounting he should adopt for the estate.

The executor is free to select any taxable year for the estate that he chooses. The year that will lead to the lowest income taxes for the estate and the beneficiaries of the estate is so intimately linked to the particular circumstances of the specific estate that no attempt will be made here to do more than point out the problem that the executor may

services started, although the ruling did not expressly condition his immunity from tax upon this fact.

${ }^{10}$ E.g., if the decedent died on March 1, 1960, before filing his 1959 income tax return, his executor would have to file a return for the decedent for 1959 on or before April 15, 1960, and another return for the decedent for the part of 1960 when he was alive on or before April 15, 1961.

${ }^{41}$ INT. REV. CODE OF 1 $954, \$ 6013$.

${ }^{43}$ INT. REV. CODE OF 1954, \& 6013(d) (3).

${ }^{13}$ ARK. STAT. \$ 62-2412.1 (Supp. 1959); Colo. REV. STAT. ANN. \$ 152-10-19 (1953); Ill. ANn. Stat. Ch. $3, \$ 495$ a (Smith-Hurd Supp. 1959).

"It would also appear to be desirable to authorize the executor to consent to split gifts with the surviving spouse and to pay any part of the resulting gift tax from the estate that he sees fit. 
encounter. Suppose, for example, that a decedent died on June 4, 1960 and the administration of his estate will be completed by July I5, I96r. The executor may get three taxable periods for the estate in a little less than fourteen months by selecting a fiscal year for the estate that ends on June 30. Thus, the first taxable year of the estate will run from June 4, 1960 through June 30, 1960 ; the second taxable year will cover July $\mathrm{x}$, I960 through June $30, \mathrm{I} 96 \mathrm{I}$; and the third taxable year will include July I, I96.I through July I5, I96r. Although this will comminute the income of the estate into three taxable periods and multiply the estate's exemptions, it may not lead to lower income taxes if the beneficiaries of the estate are on the calendar year, since the income of the estate for the last two taxable years of the estate that end in the calendar year I96I will be taxed to the beneficiaries of the estate. ${ }^{45}$ By selecting the calendar year for the estate, the executor could have accumulated the income earned by the estate during 1960, so that it would have been taxed to the estate rather than to the beneficiaries of the estate.

Although an executor may adopt the accrual basis for the estate, he will ordinarily account for the estate's income under the cash method. In addition to simplicity, this has a certain amount of flexibility, which is, however, somewhat circumscribed by the doctrine of constructive receipt. In connection with methods of accounting for income, it might be noted that where a cash-basis decedent leaves United States Savings Bonds, the executor may throw the accrued interest on the bonds into the decedent's income by electing to report the increase in surrender values as income under section 454 of the r 954 Code on the decedent's return. On the other hand, the executor may, if he chooses, defer the realization of any income from the bonds until they are actually cashed in.

\section{Income of the estate}

In reporting the income of the estate, the executor must be sure not to include income that does not belong to the estate. For example, in some states, real estate passes directly to the heir or devisees and is not part of the estate subject to the executor's control. The income from such property does not belong to the estate and should not be reported as part of the estate's income.

\footnotetext{
${ }^{45}$ INT. Rev, Code of 1 954, \$662(c).
} 


\section{Income in respect of a decedent}

Care must be taken to distinguish income in respect of a decedent from the other income of an estate because of the tax advantages and disadvantages connected with income in respect of a decedent. Income in respect of a decedent is income to which a decedent was entitled at his death, but which was not included in the decedent's income because of his system of accounting. ${ }^{46}$ For example, salary due a cash-basis decedent that had not been received, either actually or constructively, by the decedent before his death would fall into this category. Income in respect of a decedent is taxable to the estate when it is collected by the executor or to a distributee of the estate if he collects it.

One of the tax advantages connected with income in respect of a decedent is that since it is taxed under the estate tax as well as the income tax, the person to whom the income is taxed is allowed a deduc- . tion against the income tax for the proportionate part of the estate tax paid upon the right to such income. ${ }^{47}$ For example, suppose that $A$, a cash-basis taxpayer, dies and leaves claims upon which there is $\$ 1,000$ in accrued interest. After $A$ 's death, another $\$ \mathrm{I}, 000$ in interest accrues and his executor collects the $\$ 2,000$ interest. It is important for the executor to remember that $\$ I, 000$ of this interest represents income in respect of a decedent in order to claim a deduction for the estate tax paid in connection with it. Another tax advantage connected with income in respect of a decedent is that it is treated as the same kind of income in the hands of the person who succeeds to the right to the income as it was in the hands of the decedent. Thus, for example, a person who collects compensation due a decedent for an employment extending over thirty-six months may compute the tax upon the compensation under section I3OI upon the same "spread back" basis that the decedent could have used if he had collected the compensation.

The principal drawback connected with income in respect of a decedent is that the estate does not get the stepped-up basis for such income that it gets for other property acquired from a decedent. It is important, therefore, to separate income that is not income in respect of a decedent from income in respect of a decedent to avoid paying a greater tax than is due. For example, suppose that $A$ purchased Ioo shares of $X$ Corporation stock for $\$ 10,000$ and roo shares of $Y$ Corporation stock for $\$ 10,000$, and both lots of stock increased in value until they were

\footnotetext{
${ }^{* 6}$ INT. REv. CODE OF 1954, § 691.

*INT. REv. CODE OF 1954, \&69I(c).
} 
worth $\$ 100,000$ apiece at $A$ 's death. Assume further that $A$ sold the I00 shares of $X$ Corporation stock for $\$ 100,000$ before his death, but he did not receive the purchase price, while he entered into an àgreement by which he bound his executor to sell the roo shares of $Y$ Corporation stock for $\$ 100,000$ after his death. The $\$ 90,000$ gain from the sale of the $X$ Corporation stock would be income in respect of a decedent, which would be taxed to the executor when he collected it to the same extent as it would have been taxable to the decedent himself. However, since the decedent did not sell the $Y$ Corporation stock, but this was sold by his executor, the estate gets a stepped-up basis for the stock, which equals the selling price, so that there is no taxable gain from the sale of the stock. ${ }^{48}$

It is particularly important to distinguish income that is not income in respect of a decedent when an executor sells crops and farm produce after the death of a farmer. As long as the farmer himself did not make the sale, the proceeds of the sale do not represent income in respect of a decedent. Consequently, although the farmer would have realized income if he had sold the farm products, they may be sold by his executor without realizing any gain, provided the selling price does not exceed the stepped-up basis for the products to the estate. ${ }^{49}$

\section{Administration expenses and casualty losses}

Many administration expenses, along with casualty and theft losses incurred during the administration of an estate, may be deducted for purposes of either the estate tax or the income tax, but not both..$^{50}$ Although the executor should deduct these items where their deduction will produce the greatest tax benefit, this may result in discriminating in favor of one class of beneficiaries and lead to litigation..$^{51}$ To eliminate these problems, the executor should be expressly authorized to deduct administration and casualty losses in computing either the income tax or the estate tax, as he sees fit, and to make whatever adjustments to the beneficiaries' interests because of the deductions that he thinks equitable.

In connection with administration expenses, which may be deducted in computing the income tax or the estate tax, but not both, it is im-

\footnotetext{
${ }^{48}$ Treas. Reg. § 1.69i-(a) (2), example 4 (1957).

${ }^{4}$ Id., example 5 .

${ }^{50}$ INT. REv. CODE OF 1954, $\$ 642(\mathrm{~g})$.

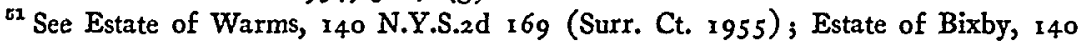
Cal. App. 2d 326, 295 P.2d 68 (1956).
} 
portant to distinguish deductions in respect of a decedent, ${ }^{52}$ which are deductible for the purpose of both taxes. A deduction in respect of a decedent is a deduction that was incurred by the decedent but could not be deducted on his return because of his system of accounting, like a property tax accrued at the death of a cash-basis taxpayer. Deductions in respect of a decedent are deductible both in computing the estate tax and the income tax of the estate. Thus, for example, the property tax referred to above could be deducted from the decedent's estate tax as a claim against his estate and as a tax paid by the estate from the estate's income tax.

\section{Alternate valuation date}

Since the basis of property acquired from a decedent is the fair market value of the property at the date of the decedent's death or the alternate valuation date if that date was used to value his estate under the federal estate tax, ${ }^{\bar{j} 3}$ it is obvious that the valuation date selected for purposes of the estate tax may affect the income tax of the beneficiary of the estate. In some cases, it may be prudent to value an estate according to the date that gives the higher value in order to trade a higher estate tax for a higher income tax basis and a lower income tax. ${ }^{54}$ The possibilities of tax savings here can constitute an embarrassment to the executor where the income tax benefit and estate tax detriment affect different beneficiaries of the estate. To protect the executor from being whipsawed between the conflicting interests of the beneficiaries, a clause may be put in the will requiring him to value the estate according to the date that leads to the lowest value for estate tax purposes. Since this will eliminate the opportunity for tax maneuvering on the part of the executor, it may be preferable to expressly authorize the executor to value the estate according to whatever date he selects, without being accountable to the beneficiaries of the estate for his selection.

\section{Timing the distributions of the estate}

Since the throwback rule does not apply to estates, the executor should time the distributions of the estate so that the income of the estate will be taxed to the estate and the beneficiaries of the estate in

\footnotetext{
${ }^{5}$ INT. REv. CODE OF 1954, § 69 I (b).

${ }^{53}$ INT. REv. CODE OF 1954, § roI 4 (a).

st The alternate valuation date may not be used unless the value of the gross estate at the date of the decedent's death exceeds $\$ 60,000$. Treas. Reg. $\$ 20.2032-x$ (b) (x) (1958).
} 
the lowest possible brackets. If the estate is in a lower bracket than the beneficiaries of the estate, the executor should accumulate the income of the estate in order to have it taxed as the income of the estate. If the beneficiaries are in lower brackets than the estate, the executor should accelerate the distribution of the income of the estate in order to have it taxed as the income of the beneficiaries.

In distributing an estate, the executor must remember that any distributions, except bequests of a specific sum of money or specific property, that are paid out in no more than three installments and are not specifically payable from the income of the estate ${ }^{55}$ are treated as distributions of income, to the extent that the estate had distributable net income. For example, if $H$ died and left the residue of his estate to his widow and in 1960 the executor accumulated all of the income of the estate, which amounted to $\$ 20,000$, but distributed two Cadillac automobiles worth $\$ 10,000$ and household furnishings worth $\$ 10,000$ to the widow, the widow would be taxed on income of $\$ 20,000$ from the estate. One way to avoid this unhappy result would be to delay distribution of the principal of the estate until a year when the entire income of the estate was distributed.

In distributing an estate, the executor should also keep in mind the fact that if appreciated assets are used to satisfy a pecuniary legacy, the estate will realize the appreciation in the form of taxable income. ${ }^{56}$ Thus, if the executor distributes stock having a basis of $\$ 50,000$ to the estate that is worth $\$ 100,000$ at the time of disribution to satisfy a bequest of $\$ 100,000$, the estate will realize taxable income of $\$ 50,000$, although in this case the legatee will take $\$ 100,000$ as his basis for the stock.

\footnotetext{
${ }^{\mathrm{E}}$ INT. Rev. CODE OF 1954, §663(a)(1).

${ }^{53}$ Supra note 30.
} 